UDC 811.111

DOI https://doi.org/10.32782/tps2663-4880/2021.17-2.21

\title{
SEMANTIC GROUPS OF ENGLISH PHRASEOLOGICAL UNITS ON DENOTATION OF PERSON'S APPEARANCE, HIS INTELLECTUAL ABILITIES AND PHRASEOLOGICAL UNITS FOR DESCRIPTION OF THE CHARACTER TRAITS OF A MAN
}

\author{
СЕМАНТИЧНІ ГРУПИ АНГЛІЙСЬКИХ ФРАЗЕОЛОГІЧНИХ ОДИНИЦЬ \\ НА ПОЗНАЧЕННЯ ЗОВНІШНОСТІ ЛЮДИНИ, \\ П̈Ї ІНТЕЛЕКТУАЛЬНИХ ЗДІБНОСТЕЙ ТА ФРАЗЕОЛОГІЧНИХ ОДИНИЦЬ \\ ДЛЯ ОПИСУ РИС ХАРАКТЕРУ ЛЮДИНИ
}

\author{
Sheverun N.V., \\ orcid.org/0000-0002-5920-5428 \\ Candidate of Sciences in Education, Associate Professor, \\ Associate Professor at the Department of Foreign Philology and Translation \\ National Transport University
}

Lejtsyus H.M., orcid.org/0000-0001-7774-4911 Candidate of Sciences in Philology, Associate Professor at the Department of Foreign Philology and Translation National Transport University

\author{
Mozhova Ya.O. \\ orcid.org/0000-0002-7696-5613 \\ Candidate of Sciences in Philology, \\ Associate Professor at the Department of Foreign Philology and Translation \\ National Transport University
}

\begin{abstract}
Phraseology, as a science, has absorbed common and distinctive features in the thinking of nations. They are characterized by historical, cultural, expressive and stylistic shades. Phraseological units that characterize a person are valuable for solving controversial and topical problems of linguistics. They are related to phraseological semantics and reveal figurative representations of a person and his appearance, intellectual abilities, character, etc. This aspect of the study of phraseology of English and Ukrainian languages is in dynamic development. The semantics of phraseology remains a major issue in the study of phraseology. The article is devoted to the study of English phraseological units on denotation of person's appearance, his intellectual abilities and phraseology units for description of the character traits of a man. An analysis of semantic groups of English phraseological units on denotation of person's appearance, his intellectual abilities and phraseological units for description of the character traits of a man is also presented. As a result of the research it was revealed that there are different phraseosemantic groups, that is phraseological complexes connected by a common idea. The following phraseosemantic groups on denotation of person's appearance are indicated: appearance in general, face, eyes, hair, features of figure, height, age, smile, nose, beard and clothes. The intellectual abilities of a person include the following one: mental activity, thinking, memory, ability to acquire knowledge, reason, wisdom, limitations, stupidity. Phraseologisms that denote the character of the individual and his behaviour are divided into 3 groups: phraseological units that express positive, negative and neutral traits of human character. This study gave impetus to further study of translation aspects of English phraseological units on denotation of person's appearance to ensure their adequate representation in the Ukrainian language.
\end{abstract}

Key words: phraseological units, phraseosemantic groups, human appearance, intellectual abilities, human character traits.

Фразеологія як наука увібрала спільні та відмінні риси у мисленні націй. Їм притаманні історичні, культурні, експресивні й стилістичні відтінки. Фразеологічні одиниці, які характеризують людину, становлять цінність для вирішення дискусійних й актуальних проблем лінгвістики. Вони пов'язані з фразеологічною семантикою і виявляють образні уявлення про особу та її зовнішність, інтелектуальні здібності, характер тощо. Цей аспект вивчення фрразеології англійської та української мов перебуває у динамічному розвитку. Семантика фрразеологізмів залишається головним питанням у вивченні фразеології. Статтю присвячено дослідженню англомовних фразеологічних одиниць на позначення зовнішності особистості, її інтелектуальних здібностей та фрразеологізмів для опису рис характеру людини. Також подано аналіз семантичних груп англомовних фрразеологічних одиниць на позначення зовнішності особи, її інтелектуальних здібностей та фрразеологізмів для опису рис характеру людини. У результаті дослідження виявлено, що є різні фразеосемантичні групи, тобто фразеологічні комплекси, поєднані загальною ідеєю. Виокремлено такі фрразеосемантичні групи на позначення зовнішності людини: зовнішність у цілому, обличчя, очі, волосся, особливості фігури, зріст, вік, усмішка, ніс, борода й одяг. До інтелектуальних здібностей людини належать такі: розумова діяльність, мислення, пам'ять, здібності до отримання знань, розум, мудрість, обмеженість, дурість. Фразеологізми, які позначають характер особистості та її поведінку, розподілені на 3 групи: фрразеологічні одиниці, які виражають позитивні, негативні і нейтральні риси характеру людини. Це дослідження дало поштовх для подальшого дослідження перекладацьких аспектів англомовних фрразеологічних одиниць на позначення зовнішності особистості для забезпечення адекватного їх передання українською мовою.

Ключові слова: фразеологічні одиниці, фразеосемантичні групи, зовнішність людини, інтелектуальні здібності, риси характеру людини. 
Introduction of the problem. Semantics of phraseological units represent a cooperation of language and thinking. In phraseology the widely presented units are on denotation of the external and internal state of man, his intellectual activity, it means those, that have expressed anthropocentric character. Language units are examined as elements of ethnosociety, where a man plays a basic role. Different descriptions of person find the reflection in the phraseology fund of language [13, c. 198].

Analysis of recent research and publications. Linguists investigate the problems of phraseology, that have a theoretical and practical value. Interest in phraseological units from the side of linguists is widespread enough. Such domestic and foreign linguists, as D.Aladko [2], H. Burger [12], P. Wilkinson [13], M. Johnson [4], O. Klendiy [5], N. Lvova [5], N. Pavlenko [6], S. Pomyrcha [7], K. Radionova [8] and many others devoted numerous articles and monographs to research of fixed expressions. An important task is not only to investigate the theory of phraseology but also translation of fixed expressions. A process of translation is a complex process that represents an important type of speech activity. Translation is considered the perspective means of overcoming of present language barriers. Exactly due to fixed expressions a connection is established with the historical past, way of life of people and language. However, analysis of semantic groups of phraseological units on denotation of appearance of person, his intellectual capabilities and phraseological units for description of character of man traits continues to remain actual.

Scientific novelty of the article is that it proposes the analysis of semantic groups of English phraseological units on denotation of person's appearance, hisintellectual abilities and phraseological units for description of the character traits of a man.

The main purpose of the study is realization of analysis of semantic groups of English phraseological units, that describe appearance, mental abilities and character of man traits.

To achieve the goal of the research, we used a set of methods. They are based on a communicative-functional approach and include theoretical analysis of special literature on the research topic, selection of texts for analysis using selective-analytical and contextual methods of English-language phraseological units research and and identification appropriate phraseosemantic groups of phraseological units on denotation of person's appearance, his intellectual abilities and phraseological units for description of the character traits of a man.

Results and discussions. Phraseology composition, as well as vocabulary, forms group after semantic classes. Phraseological units form lexical, lexico-phraseological and phraseological semantic groups. Phraseological units are formed on various signs: integrity of nomination, metaphorical, equivalence to the word, producibility. For the analysis of semantics of phraseological units the method of authentication is used. It consists in the selection of abstract words or wordcombination for determination of general meaning of phraseological unit. Every component of semantic structure of phraseological unit is directed to mark certain descriptions and consists in evaluation activity of human consciousness. Polisemanticy, antonymy, synonymy are characteristic features of phraseosemantic group. Phraseosemantic group is totality of fixed verbal complexes that is connected by a general idea. For example, to thematic classification of scientist B. Azhnyuk about 900 phraseological units concerning a man behave: intellect, thinking, capabilities of man; appearance of man; character of man traits; emotions and feelings; human activity and behaviour; relationships with other people, welfare/poverty, success/failure refers [1, c. 64].

There are also other classifications, one of which is distribution of fixed expressions of scientist V. Suprun into the following groups: intellect, anomalous states of man; descriptions of man and emotions; relations between people; wealth [9, c. 71]. A significant number of idioms in phrase formation is related to perception of the world, that is associated with life, human feelings, mental work, character.

It is possible to distinguish such phraseosemantic groups on denotation ofman's appearance: appearance on the whole, face, eyes, hair, features of figure, height, age, smile, nose, beard and clothing. The common impression from a man is from his original appearance, figure, face. The general estimation of appearance is underlined structurally by different turns, mainly by comparisons: graceful as a swanвитончений як лебідь, fair as a lily-гарна, яклілія, heavy swell - людина з ефектною зовнішністю, not a hair out of place - людина, яка має чудовий вигляд. Mostly they are characterized by positive emotions. Accordingly an unattractiveness is passed by expressively-emotional turns. Comparisons can have cruel character, that is why there are comparative turns in the language system of all people. They characterize brightly the lacks of appearance of man. For example: ugly as sin-cmрашний як смертний гpix, ugly duckling - гидке каченя.

In order to analyse character of man in general, it is necessary to pay attention to detail, in particular on a face, eyes, hair, height, clothing, and others like that. An estimation is first given to the features of person, 
so as generally speaking that strikes the eyes is perceived. For description of different human signs and his original appearance irony and waggery are used. There is a group of physical defects of man, that can be born or purchased. External signs that touch the colour of skin are also presented. A complexion allows to expose the emotional state of man, in particular excitement or gladness. Person, who is afraid or worries: as white as a sheet - блідий як полотно, to turn white - збліднути, ears become red-nокрасніти. Consider that a face of man is a mirror of the soul among that eyes play one of major details. For example: have stars in one's eyes - oyi сіяють від щастя, naked еуе - неозброєне око, black eуe - підбите око. For the estimation of appearance of man a phraseosemantic group "hair" is also marked. For example: as bald as a coot иілком лисий, hell of hair - нечесане волосся.

The largest phraseosemantic groups are "appearance on the whole" and "features of figure". First consider the description of figure's features on a physical sign "thick-thin". Obviously, that megascopic weight and exorbitance in a meal was considered a human defect. In a group "thin" the lexemes of "bone" and "skin" are mainly used. They are characterized by a tinge of contempt. For example: as dry as a bone - сухий, мов кістка, walking corpse-живий скелет, шкіра та кістки. A thin man in Ukrainian is compared to the board, sliver, whereas Englishmen compare it with rakes, rails: as thin as a rake-худий як тріска. Description of man by means of turns with a zoomorphic component is used often enough [10, c. 102]. With unattractive appearance a man is associated with a pig. For example: as fat as a pig. Such comparisons are used also as: plump as a partridge - пухлий, як пампушка, round as a barrel-товстий, як бочка.

Another description is height. Phraseological units that characterize a tall man are expressed by hyperbolae and comparisons. For example: as long as one's arm - дуже високий. For description of low people litote is used: vertically challenged недорослий, Jack Sprat-низькийзростом, від землі не видно. There is also a number of phraseological units that contain the expressivity concerning a height, for example: going strong - в розквіті сил, bear one's age well - виглядати молодше свойх років, old boat - стара калоша, long in tooth бути старим, аж пісок сиплеться.

A smile always expresses a positive mood. That is why fixed expressions contain a positive estimation: grin from ear to ear-nосмішка до вух.

An important semantic group is a group, that describes a human nose. It can be of normal proportions and even, and sometimes with curvature or hump. In English phraseological units on denotation to the nose are apt to the associations. For example: Roman nose, aquiline nose - ніс з горбочком, button поге - ніс тудзиком.

Another element that touches a face is a beard. It can be different colour in accordance with a hair colour, and also original form. It is possible to give an example such as: polar beaver - людина із сивою бородою, Vandyke beard - борідка клином.

Original appearance of man considerably depends on his clothing. It is demonstrated by turns on denotation of his exactness, cleanness and style. such phrases can belong to this group, as: just out of a bandbox - одягнений з голки,dressed in the height of fashion - одягнений за останньою модою, dressed to kill - людина вдягнута дуже святково.

On the whole phraseological units are figurative and emotional, that is why due to their analysis it is possible to find out the cultural and national symbols of human mental abilities. Often enough a lexeme comes forward as a supporting component голова - head, that describes its form, content, absence of rumour, and others like that. For example: have an old head on young shoulders - голова на плечах, a wise head-мудра голова.

To the intellectual capabilities of man such phraseosematic groups belong: intellection, thinking, memory, capacities for the receipt of knowledge, mind, wisdom, limit nature, foolishness. They contain phraseological units, that represent memorizing, recreation, maintenance of information. Basic components are such lexemes, as brain, wise, memory: not to have a brain in one's head - солома в головi, a word is enough to the wise - розумний розуміс з півслова, have a memory like an elephant-мати пам'ять як у слона. In different languages the same concept can be transmitted by various components. For example, in Ukrainian in fixed expressions there is a lexeme "stave", while in English such concept is expressed through the lexeme "button".

In a phraseosemantic group "intellection, thinking" phraseological units describe thinking as process, that is sent to the object. For example: look before and after - зібратись з думками. There are lexemes that characterize such processes as mind, memory. A mind is examined not only as ability to understand and think, but also as a thinking organ. An intellect refers to mental abilities and includes experience, knowledge, and also ability to the study and use of these knowledge. For example: know his stuff-мати хороші знання, something on the ballмати здібності. 
The level of mental abilities can hesitate. Phraseological units with negative estimation of mental abilities prevail from inclination of people to reprobate defects through criticism, neglect and irony. For example: fools have fortune - дурням uзастить, off one's rocket - бути не сповна розуму, neither here nor there - ні до села, ні до міста. Such evaluation is the permanent debatable question of philosophers and linguists, since what is important to one nation, may not be important for another.

There is a number of phraseological units that mark character of personality and his behaviour on the whole. The concept of personality is related to the individual features of man with character of public relations and influence both own and public development. For everybody social persuasions that recreate his inner world in behaviour and attitude toward wider public are certain. Behaviour of man is examined as a difficult complex that is sent to satisfaction of physiology, spiritual and social necessities. It is formed on the basis of many components. Behaviour of man consists of reactions, emotions, intellectual capabilities, habits, skills, relations between people, perception of environment. At present there are many approaches in relation to the types of human behaviour. Among most wellknown there are such as: theory of I. Kant, where behaviour is determined by the call of duty, theory of A. Maslow and F. Herzberg, where behaviour of people is linked to their needs. However in the first turn character, emotions and feelings influence on human behaviour forming [11].

Phraseological units that mark human character, incarnate cultural and national perception of the world in the vivid manner, so as in the language system of the English and Ukrainian languages where phraseological units gained a foothold and purchased a meaning that correspond their cultural and national standards.

A linguist B. Baisarov marked about the bilateral structure of character, namely dynamic and rich in content aspect. Under a dynamic side mean behaviour of man, and under rich in content are reasons of personality. The rich in content aspect of human character is shown in phraseological units of both languages as determination of different character traits. A dynamic aspect includes description of behaviour of man, that is conditioned by the features of character and actions of man. In foreign psychology to character take all displays of psychical life of man, equating a concept "personality" and "character". However such understanding can be taken for basis at the selection of phraseological units, so as it extends research material without restriction and does not promote them to the exact analysis [3, c. 49].
Phraseological units are analysed in accordance with the evaluation component of phraseology meaning. Exactly an evaluation component is the basic conotative meaning of phraseological unit. It can be either approving or disapproving estimation. The subjectively-evaluation element of phraseological unit can be explained by differentiated reaction of people on the positive and negative phenomena. In the semantic structure of phraseological units distinguish the positive, negative and neutral components of phraseology meaning. In their basis approvals, conviction or absence of the brightly expressed relation lie as a socially withstand estimation of any human phenomenon.

Phraseological units that express negative character of man traits belong to the first group. Both in English and Ukrainian languages they fold the most numerous group. This is explained by more emotional reaction on the negative phenomena, and also by the tendency of drawing on the fixed verbal complexes of characteristic for the negative emotional states.

To the phraseosematic sub-groups of phraseological units of negative estimation fixed expressions with a general meaning about hypocrisy, meanness, boasting, cruelty, avidity, insolence, unscrupulousness, cunning, rudeness, lack of restraint, obstinacy, rancour, envy, lazinesses, secrecy, negligence, inclination to gossip, dishonesty, cowardice, mercenariness, irresponsibility, capriciousness are taken. They present considerable interest in force of their unicity, uniqueness. The presence of such phraseological units in a language testifies that phraseology of every language, except general lines that draw it together with other languages, has something, conditioned by not only the internal laws of development but also character of perception of the phenomena of surrounding reality of his transmitter [3, c. 54-56].

For denotation of negative character traits the following phraseological units are used, for example:

- hypocrisy, treachery: heel, snake in the grass, bear two faces under one hood, sly dog, wolf in sheep's clothing, an old bird is not caught with chaff;

- boasting: a high horse, proud as a peacock, smart aleck, aim at the moon, as conceited as a barber's cat;

- cruelty, rudeness: thick-skinned,as gruff as a bear, a heart of stone, be full of vinegar, hard as a flint, hard-boiled egg, have no bowels mouth off;

- avidity: the cat, be full of oneself, hoggish, an itching palm, basket case, tame cat, closefisted with money; 
- cowardice: be afraid of one's shadow, timid as a hare, yellow dog, yellow-bellied, hide one's head in the sand, scaredy-cat;

- spinelessness: to follow like sheep, a worm, man of no character, nose of wax, spineless, weak as water, doormat;

- frivolousness: light as butterfly, scatterbrain;

- curiosity: nosey Parker; peeping Tom;

- lazinesses: let the grass grow under one's feet, twiddle one's thumbs, to idle away one's time;

- cunning, dishonesty: as cunning as a fox, as crooked as a dog's hind leg;

- obstinacy: as stubborn as a mule, as obstinate as a donkey, hard-nosed, have a closed mind about something;

- lie: foul play, to be eavesdropping, false testimony, a white lie;

- gossip: have a big mouth, sharp tongue.

To this group it is also possible to take such phraseological units as: hard-nosed - впертий, with nose in the air - зверхня людина, have a big head-nихатий.

From examples set above it is possible to analyse that zoomorphic components, are often used in the structure of such expressions, which also present metaphorical feature.

Phraseological units that express positive character of man traits belong to the second group. They are less more numeral, than phraseological units with a negative meaning, however also occupy a ponderable place in the phraseology fund of the English and Ukrainian languages.

To this group phraseological units with the positive subjectively-evaluation component of phraseology value belong, in particular such, that causes approval, respect as establishment of a socially withstand estimation of certain character of man traits $[3$, c. $54-56]$.

To the phraseosemantic sub-groups of phraseological units of positive estimation expressions with a meaning about restraint, decision, boldness, sincerity, honesty, diligence, energeticness, independence, loyalty, blitheness, kindness, modesty, heartiness, optimisticness, justice, generosity, communicability, punctuality and others are taken [3, c. 54-56]. Comparisons and vividness are also referred to them.

For denotation of phraseosemantic sub-groups of positive character traits of a person the following phraseological units are used, that express:

- restraint, calmness: a cool heart, mental ballast, put a good face on smth, in one's sober senses, sober as a judge, clear (hard) grit, hard as nails, level head, good man;
- sincerity: single heart (mind), as open as the day, plain dealer, make a clean breast of smth, he is an open look, to be open-hearted;

- honesty: play a straight bat, treat smb white, (as) straight as a die, as honest a man as ever broke bread, as honest a man as ever trod on earth, shoe leather, honest, as honest as the skin between his brows, the clean thing, clean hands, straight goods, straight dealing fair play, kind (honest, simple) soul, clean liver, fair play, honest as a day, open-minded, true penny, good men and true, square shooter;

- a decision, reliability: stout heart, a strong man, firm (steady) as a rock, a hard nut to crack, a tough nut;

- industriousness: a willing horse, (as) busy as a bee (busy as a beehive; as a beaver, as a hen with one chicken; busy as a cockroach on a hot stove; as a one-armed paperhanger), work double tides, work at high pressure, work one's fingers to the bone, bust a gut, keep one's nose to the grindstone;

- nobleness: a big heart, a high mind, good as gold, good as pie, good nature;

- blitheness: merry as a cricket (grig, a marriage bell, as maids), playful as a kitten,light heart, free liver, cheerful (gay) as a lark, fresh as a daisy (a rose; as paint, as new paint; flowers in may), free and easy, see through rose-coloured glasses;

- kindness, affability, heartiness: a kind (honest, simple) soul, kind (soft, warm) heart, big heart;

- devotion, loyalty: true as flint, true as the needle to the pole, true as steel, every dog has his day, bear pool, birds of a feather flock together;

- politeness: all things to all man, bland as oil, keep a civil tongue;

- decision: a man with plenty of guts, steady as a rock;

- sympathy, mercifulness: be milk of human kindness, have a heart, man of feeling, man of heart;

- shrewdness, reasonableness: man of sense, sober as a judge, man with brains, have a ready wit;

- penetrating: : astounding card, long-headed, sharp as a needle, smart as as pain;

- courage: man of courage, husky, bold spirit, man of horseback, gutsy, dogs of war, to put one's head in the lion's mouth, to take a bear by the tooth, find it in one's heart to do sometning.

To this group it is also possible to take such phraseological units as: keep one's wits about one не втрачати голови, heart goes out to someone співчувати комусь, as gentle as a lamb - ніжний, лагідний. Phraseological units on denotation of positive character traits represent different aspects of human life and contain components that are related to the human organs. 
Phraseological units that mark the neutral estimation of character of man traits and fold insignificant part among other belong to the third group. This group does not enter to two basic. Fixed expressions with neutral component of phraseology meaning, that are lack of brightly expressed approval or conviction belong to this group. They have so-called transitional character that depends on a situation. Depending on it their meaning can acquire different tints of positive or negative estimation. To such qualities, the following can be referred: a queer bird (card, cove, duck) -дивна людина; as mild as a dove (lamb, as May, milk) - сумирний; wide awake - обережний, стріляний горобещь. Tо this group also belong such character traits as:

- uncertainty, indecision: buridan's ass, a donkey between two bundles of hay, halfhearted;

- lack of upbringing: be with bad form, black man;

- toadying: tame spaniel, hay it on with a trowel;

- a quick temper: ants in one's pants, as hot as pepper, hothead, hotter than a pistol, man of action, slippery as an ell;

- equanimity, tolerance: bear and forbear, have iron nerve, cool head, man of nerve, keep a level head, cool as cucumber.

Phraseological units from this group can have neutral meaning that does not depend on a context, for example: negative virtue - пасивна людина; еasy game (prey, mеat) - довірлива, сердечна людина, bats in the belfry - ексиентричний.

Thus, three groups of phraseological units on denotation of human character traits are analysed among which the negative lines of person prevail.
Conclusions. Examining phraseological units, that represent refinement of details of appearance, character and intellectual capabilities of man traits, it is possible to draw conclusion, that the features of their structure and meaning are distinguished through their comparing to realities of way of life and surrounding world on the whole, that represent positive or negative attitude of people toward the certain phenomena. Fixed expressions are divided into different semantic groups that in turn are divided into phraseosemantic sub-groups depending on their meaning. Distribution of fixed expressions on phraseosemantic sub-groups is conducted on the basis of their authentication by separate lexemes, word-combinations or unfolded descriptions in lexicographic sources, to the presence of general integral semas in their semantics. Usually phraseology supply of every language, that consists of negative comparisons is considerably larger, as people got used to notice in every person negative lines or strange and uninherent to them, than something usual. So plenty of various comparisons and associations is conditioned, both with animals and with parts of body or other objects that express an evaluation meaning. The culture of people, their mentality and features of human way of life and mutual relations, stands by system of phraseological units. The prospect of further research is a study of the main ways of Englishlanguage phraseological units on denotation of appearance of person, his intellectual capabilities and phraseological units for description of character of man traits into Ukrainian language translation.

\section{REFERENCES:}

1. Ажнюк Б.М. Англійська фрразеологія в культурно-етичному висвітленні. Київ : Наукова думка, 1999.134 с.

2. Аладько Д.О. Характеристика людини засобами фразеологізмів з компонентом-зоонімом в англійській та українській мовах. Науковий вісник Міжнародного гуманітарного університету. Сер. Філологія. 2016. № 23. T. 1. С. 100-102.

3. Байсаров Б. Сопоставительный анализ фразеологических единиц. Казань : Издательство Казанского университета, 1990. 128 с.

4. Лакофрф Дж., Джонсон М. Метафроры, которыми мы живем. Москва : Едиториал, 2004. 256 с.

5. Львова Н.Л., Клендій О. . Семантика фразеологізмів для опису зовнішнього вигляду людини. URL : www.rusnauka.com/7_NMIW_2011/Philologia/7_81255.doc.htm.

6. Павленко Н.О. Фразеологізми на позначення людини за ії̈ здібностями в англійській мові: лінгвокультурологічний і семантичний аспекти. Науковий вісник Міжнародного гуманітарного університету. Сер. Філологія. 2018. №37. Т. 2. С. 125-127.

7. Помирча С.В. Вербалізація фрразеологічних одиниць на позначення якостей характеру людини // «Молодий вчений». №6.1 (46.1). 2017. С. 64-67.

8. Радіонова К.С. Стійкі компаративні одиниці на позначення зовнішності людини в англійській, французькій, українській та російській мовах. Науковий вісник Міжнародного гуманітарного університету. Сер.: Філологія. № 15. Том 2. 2015. С. 123-125.

9. Супрун В.И. Ономастическое поле русского языка и его художественно-эстетический потенциал. Волгоград : Перемена, 2000. 172 с.

10. Ужченко В.Д. Східноукраїнська фрразеологія. Луганськ : Альма матер, 2003. 362 с.

11. Фразеологізми англійської мови та їх переклад на українську мову. URL: http://supermif.com/ frazeologizm/england/england_ukr_fraz_a_d.html.

12. Burger H. Phraseologie. Eine Einführung am Beispiel des Deutschen. Berlin : Schmid, 2003. 240 s.

13. Wilkinson P. R. A thesaurus of traditional English metaphors. London : Routledge, 1993. 490 p. 